NIST Special Publication 1179

\title{
Impact of More Precise Electricity Price Data on Estimated Energy Costs from Energy Standard Adoption for Buildings
}

Joshua Kneifel

David Butry

This publication is available free of charge from: http://dx.doi.org/10.6028/NIST.SP.1179
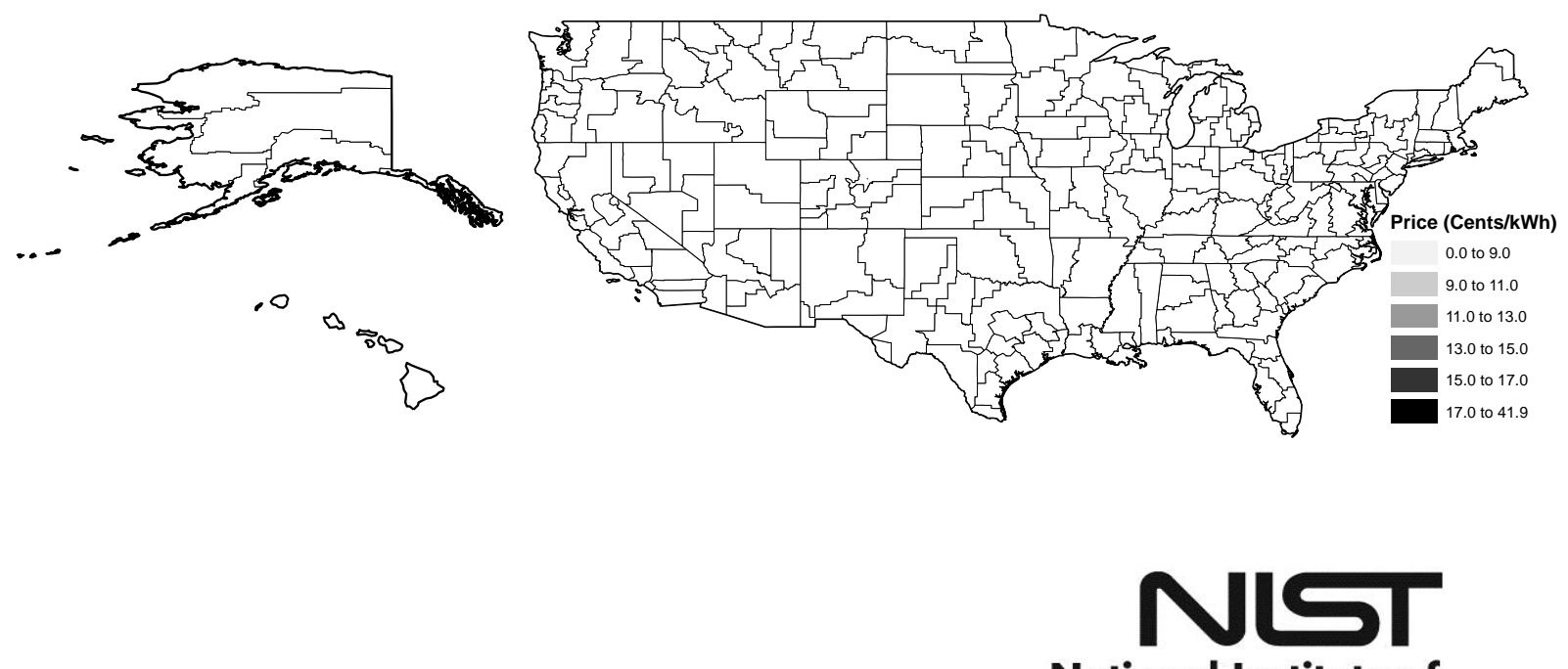

National Institute of Standards and Technology U.S. Department of Commerce 



\title{
Impact of More Precise Electricity Price Data on Estimated Energy Costs from Energy Standard Adoption for Buildings
}

\author{
Joshua Kneifel \\ David Butry \\ Applied Economics Office \\ Engineering Laboratory
}

This publication is available free of charge from:

http://dx.doi.org/10.6028/NIST.SP.1179

December 2014

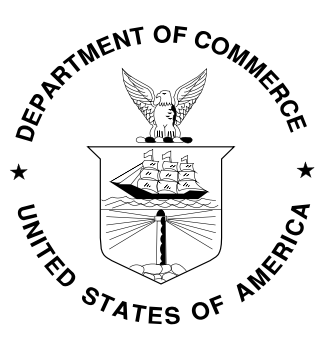

U.S. Department of Commerce Penny Pritzker, Secretary

National Institute of Standards and Technology Willie May, Acting Under Secretary of Commerce for Standards and Technology and Acting Director 
Certain commercial entities, equipment, or materials may be identified in this document in order to describe an experimental procedure or concept adequately. Such identification is not intended to imply recommendation or endorsement by the National Institute of Standards and Technology, nor is it intended to imply that the entities, materials, or equipment are necessarily the best available for the purpose.

National Institute of Standards and Technology Special Publication 1179

Natl. Inst. Stand. Technol. Spec. Pub. 1179, 15 pages (December 2014) CODEN: NTNOEF

This publication is available free of charge from: http://dx.doi.org/10.6028/NIST.SP.1179 


\begin{abstract}
Energy efficiency requirements in current building energy codes vary across states, and many states have not yet adopted the latest editions of ASHRAE Standard 90.1 for commercial buildings or the International Energy Conservation Code (IECC) for residential buildings. Some states do not have a code requirement for energy efficiency, leaving it up to the locality or jurisdiction to set its own requirement. There may be significant energy savings to be realized by states if they were to adopt more energy efficient building energy codes.
\end{abstract}

The Applied Economics Office (AEO) of the Engineering Laboratory (EL) at the National Institute of Standards and Technology (NIST) has developed the Building Industry Reporting and Design for Sustainability (BIRDS) database, which estimates the sustainability (energy, economic, and environmental) performance for eleven commercial building prototypes in each of 228 cities across the U.S. designed to different energy efficiency levels. The analysis of the BIRDS database includes estimates of both the average percentage change in energy consumption and the aggregate changes in energy consumption from the adoption of a more restrictive energy code for one year's worth of construction for each state in the nation.

At the time the BIRDS database was compiled a number of data sources were at the statelevel of precision, including new building construction data and average electricity costs per kilowatt-hour of consumption. Since both of these two factors may vary across cities within a state, the approach could lead to inaccuracies in the state-level aggregate estimations. This study implements an approach to associate every county in the U.S. to one of the 228 cities included in the BIRDS database to create multi-county "city clusters," and matches city-level average residential electricity costs to all counties in a city cluster. By defining these city clusters, the study can determine the variation in electricity prices across each state and the potential impact the variation may have on energy cost savings estimates.

The residential electricity price variation found in this study is found to vary within a state, anywhere from $0 \%$ to $168 \%$. As a result, using city-level electricity prices instead of state average prices may have a significant impact on analysis of the upcoming new residential buildings addition to the BIRDS database.

\title{
Keywords
}

BIRDS; buildings; energy efficiency; residential electricity prices; sustainability; whole building energy simulation 


\section{Preface}

This study was conducted by the Applied Economics Office (AEO) in the Engineering Laboratory (EL) at the National Institute of Standards and Technology (NIST). The study is designed to compare the sensitivity of estimated savings from energy standard adoption using more precise construction data. The intended audience includes researchers in the building sector concerned with energy performance in buildings.

\section{Disclaimers}

The policy of the National Institute of Standards and Technology is to use metric units in all of its published materials. Because this report is intended for the U.S. construction industry that uses U.S. customary units, it is more practical and less confusing to include U.S. customary units as well as metric units. Measurement values in this report are therefore stated in metric units first, followed by the corresponding values in U.S. customary units within parentheses. 


\section{Acknowledgements}

The authors wish to thank everyone for their advice and recommendations for the writing of this report, including Douglas Thomas and Dr. Robert Chapman of EL's Applied Economics Office, Dr. David Holmberg of EL's Energy and Environment Division, and Dr. Nicos S. Martys of EL's Materials and Structural Systems Division.

\section{Author Information}

Joshua D. Kneifel

Economist

National Institute of Standards and Technology

100 Bureau Drive, Mailstop 8603

Gaithersburg, MD 20899-8603

Tel.: 301-975-6857

Email: joshua.kneifel@nist.gov

David Butry

Economist

National Institute of Standards and Technology

100 Bureau Drive, Mailstop 8603

Gaithersburg, MD 20899-8603

Tel.: 301-975-6136

Email: david.butry@nist.gov 


\section{Contents}

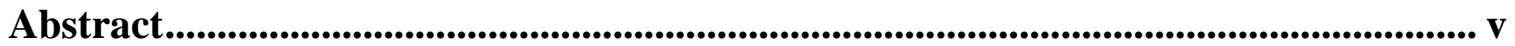

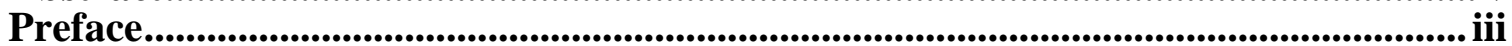

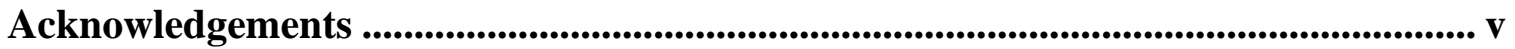

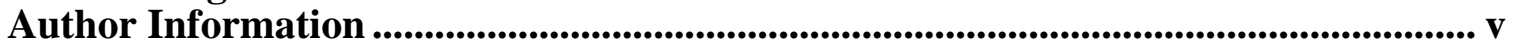

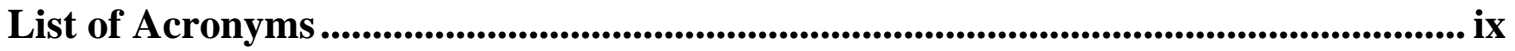

1 Introduction ........................................................................................................................ 1

2 State-Level versus City-Level Electricity Prices ........................................................... 5

3 Discussion, Limitations, and Future Research .................................................. 11

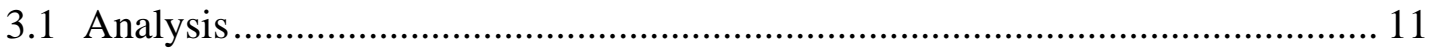

3.2 Limitations and Future Research............................................................... 11

References ................................................................................................................................................ 13

A Electricity Prices by State .................................................................................................... 15

\section{List of Figures}

Figure 1-1 Cities and Associated County Clusters ..................................................... 2

Figure 1-2 New Floor Area by County Cluster ........................................................ 2

Figure 2-1 Electricity Price (Cents/kWh) by (a) State Average and (b) County Cluster .. 6

Figure 2-2 Average Electricity Price (Cents/kWh) by City Cluster for New York.......... 7

Figure 2-3 Variation in City Cluster Electricity Prices by State in (a) Cents/kWh and (b)

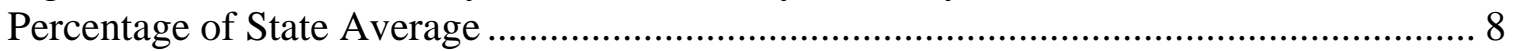

Figure 3-1 City Clusters - Kentucky and Surrounding States...................................... 12

Figure A-1 Electricity Price by State Average and County Cluster (Cents/kWh).......... 15

\section{List of Tables}

Table 2-1 Top 10 - State Average Price and Variation in City-Cluster Electricity Prices

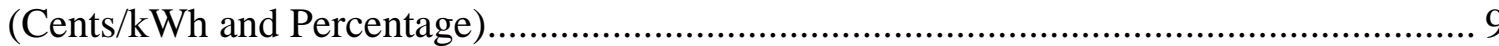




\section{List of Acronyms}

\section{Acronym Definition}

AEO Applied Economics Office

ASHRAE American Society of Heating, Refrigerating and Air-Conditioning Engineers

BIRDS Building Industry Reporting and Design for Sustainability

CBECS Commercial Buildings Energy Consumption Survey

EIA Energy Information Administration

EL Engineering Laboratory

NIST National Institute of Standards and Technology 


\section{Introduction}

Energy efficiency requirements in current building energy codes vary across states, and many states have not yet adopted the latest editions of ASHRAE Standard 90.1 for commercial buildings or the International Energy Conservation Code (IECC) for residential buildings. Some states do not have a code requirement for energy efficiency, leaving it up to the locality or jurisdiction to set its own requirement. There may be significant energy savings to be realized by states if they were to adopt more energy efficient building energy codes.

The Applied Economics Office (AEO) of the Engineering Laboratory (EL) at the National Institute of Standards and Technology (NIST) has developed the Building Industry Reporting and Design for Sustainability (BIRDS) database, which estimates the sustainability (energy, economic, and environmental) performance for eleven commercial building prototypes in 228 cities across the U.S. designed to different energy efficiency levels. ${ }^{1}$ The analysis in Kneifel (2013a, 2013b, 2013c, 2013d, 2013e) uses the BIRDS database to estimate both the average percentage change in energy consumption and the aggregate changes in energy consumption for one year's worth of construction for each state in the nation.

At the time the BIRDS database was compiled a number of data sources used were aggregated at the state-level of precision, including new building construction data and average electricity costs per kilowatt-hour of consumption. Since both of these two factors may vary across cities within a state, the method to aggregate data to the state level could lead to inaccuracies in the state-level estimates shown in Kneifel (2013a, 2013b, 2013c, 2013d, 2013e).

Kneifel and Butry (2014) defines an approach to associate every county in the U.S. to one of the 228 cities included in the BIRDS database to create multi-county "city clusters," and then matches recently acquired county-level new construction data to city-clusters in BIRDS. A county is matched to the closest city in its state based on distance to the city from the centroid (geometric center of a two-dimensional region) of the county within the same climate zone. ${ }^{2}$ If there is not a city located in the same climate zone within the state, then the closest city located within the same state is selected. Of the 3140 counties, 2911 counties are matched to a city within the same climate zone while 229 are matched to a city not within the same climate zone. The city clusters are shown in Figure 1-1.

\footnotetext{
${ }^{1}$ For details on the design of the BIRDS database, see Kneifel (2011) and Kneifel (2012).

${ }^{2}$ Matching is done by climate zone because building energy standard requirements vary by climate zone.
} 

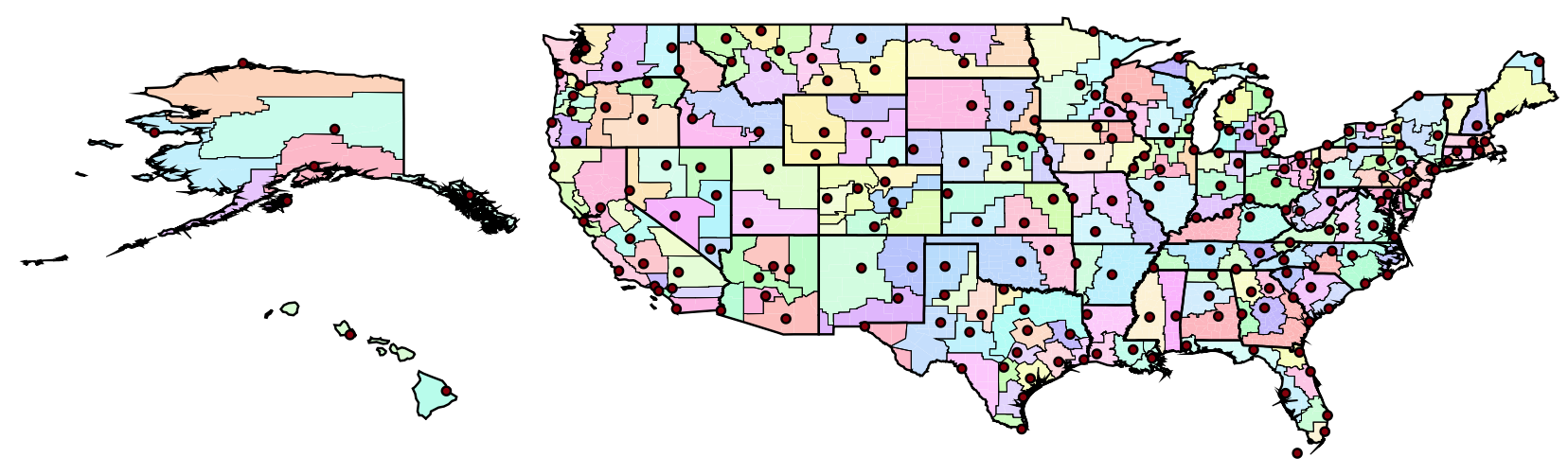

Figure 1-1 Cities and Associated County Clusters

Figure 1-2 shows the new floor area constructed in 2012 by county cluster as developed in Kneifel and Butry (2014). Instead of weighting each city equally, the city cluster new floor area is used to weight each city's estimated energy savings. Depending on the state, the importance of more appropriately weighting the average savings for each city cluster may have a significant impact on the state-level results as estimated in Kneifel (2013a, 2013b, 2013c, 2013d, 2013e). For example, major city clusters in Texas (Dallas/Fort Worth, Austin, and Houston) are realizing new construction of over 3.7 million $\mathrm{m}^{2}\left(40.0\right.$ million $\left.\mathrm{ft}^{2}\right)$ while northern Texas clusters have construction of less than $372000 \mathrm{~m}^{2}$ (4.0 million $\mathrm{ft}^{2}$ ). As a result, the approach implemented in the previous approach would lead to an overvaluing of energy savings differences at the state level from north Texas clusters, while undervaluing any savings in the major cities.

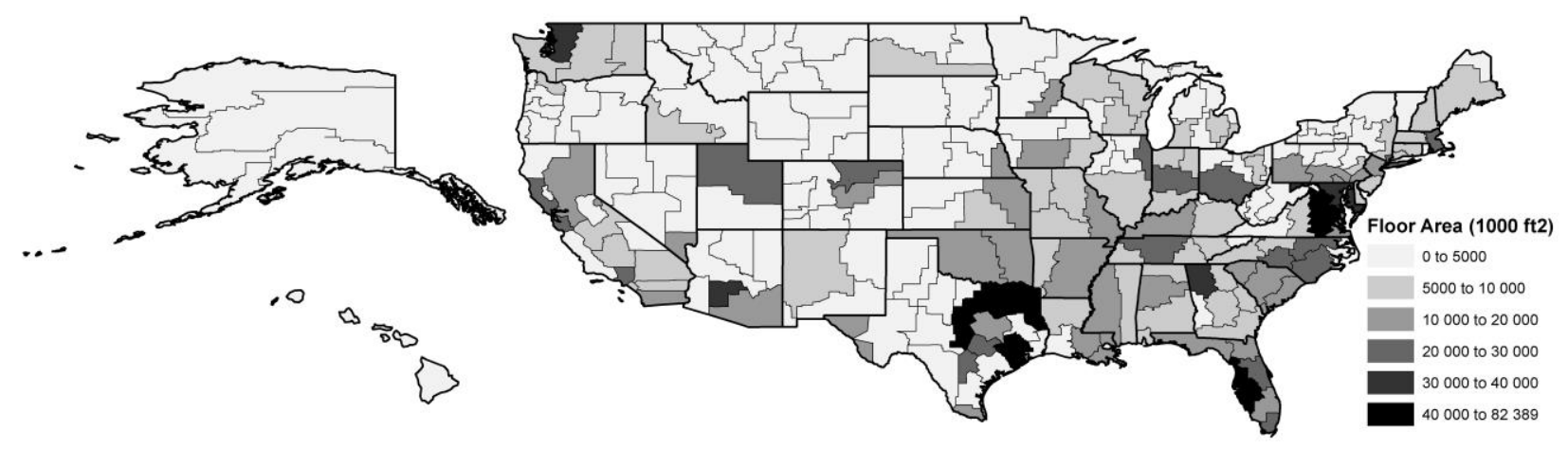

Figure 1-2 New Floor Area by County Cluster

The city clustering approach can be applied to both the commercial sector and the residential sector because the city-county matching is based on distance and climate zone, both of which are independent of construction sector. This study implements the city clustering approach to match 
city-level average residential electricity costs to all counties in a city cluster to determine the variation in electricity prices across each state and the potential impact the variation may have on energy cost savings estimates based on the upcoming new residential buildings addition to the BIRDS database. 


\section{State-Level versus City-Level Electricity Prices}

Although the electricity costs in the original BIRDS database formulation are estimated for buildings in each of the 228 cities, the costs are based on state average prices of electricity (cents per kilowatt-hour) compiled by the Energy Information Administration (EIA) as shown in Figure 2-1a. ${ }^{3}$ These state average prices are calculated by taking the weighted average price of all utility sales in a state as shown in Equation 1. Market share is the total electricity sales by utility $u$ in the state divided by total electricity sales for all utilities in the state.

(1) $P_{j}=\sum_{u_{j}}^{U_{j}}\left(P_{u, j} * M_{u, j}\right)$

$$
\begin{aligned}
& \text { Where } \quad M_{u, j}=\frac{s_{u, j}}{\Sigma_{u_{j}}^{U_{j}}\left(s_{u, j}\right)}=\text { market share of utility } u \text { in state } j \\
& P_{j}=\text { average electricity price for state } j \\
& P_{u, j}=\text { average electricity price for utility } u \text { in state } j \\
& S_{u, j}=\text { total sales for utility } u \text { in state } j \\
& U_{j}=\text { set of utilities in state } j
\end{aligned}
$$

As a result, there may be inaccuracies in the electricity cost estimates in the BIRDS database. In particular, states with greater variability in prices will have less accurate electricity cost estimates. Greater variability in electricity prices would be expected in states that have a large amount of land mass, significant differences in electricity demand due to population density, and details of electricity grid infrastructure design.

The approach implemented in this study calculates the average residential cost of electricity per kilowatt-hour for each of the 228 cities in the BIRDS database, matches these prices to the counties for each city cluster as defined in Kneifel and Butry (2014), and compares these values to the state average electricity price reported by the EIA.

Each city in the U.S. has one or more electric utilities that meet the electricity demand for a city, with varying market shares and prices. Utility-level data was obtained from Table 6 in EIA (2012b), which includes data from Forms EIA-861- schedules 4A \& 4D and EIA-861S that include information on the number of customers, sales, revenues, and average price by utility.

The city-level electricity price is calculated by identifying the utilities for each city and calculating the average price for the city based on the market share (total sales in MWh) and average price $(\varnothing / \mathrm{kWh})$ for each utility in a city as shown in Equation $2{ }^{4}$

\footnotetext{
${ }^{3}$ EIA (2012a)

${ }^{4}$ The total number of customers was considered as an alternative measure of market share instead of total sales to determine if there is any sensitivity to the resulting average weighted price for a city. The average price estimates using the total number of customers are nearly identical to the prices using total sales, alleviating any concern that the estimates are sensitive to the market share measure.
} 
(2) $P_{k}=\sum_{u_{k}}^{U_{k}}\left(P_{u, k} * M_{u, k}\right)$

Where $\quad M_{u, k}=\frac{s_{u, k}}{\Sigma_{u_{k}}^{U_{k}}\left(S_{u, k}\right)}=$ market share of utility $u$ in city $k$

$P_{k}=$ average electricity price for city $k$

$P_{u, k}=$ average electricity price for utility $u$ in city $k$

$S_{u, k}=$ total sales for utility $u$ in city $k$

$U_{k}=$ set of utilities in city $k$

The city-level electricity price $\left(P_{c}\right)$ is then associated with all the counties in the city's "cluster" as defined in Kneifel and Butry (2014). Figure 2-1b shows the county clusters associated with the cities in the BIRDS database. By comparing Figure 2-1b to Figure 2-1a, it is clear that electricity prices not only vary among states ( $7.7 \phi / \mathrm{kWh}$ to $35.4 \phi / \mathrm{kWh})$, but can vary among city clusters within a state. This variation leads to a state average price that is not truly representative of much of the state as a whole.
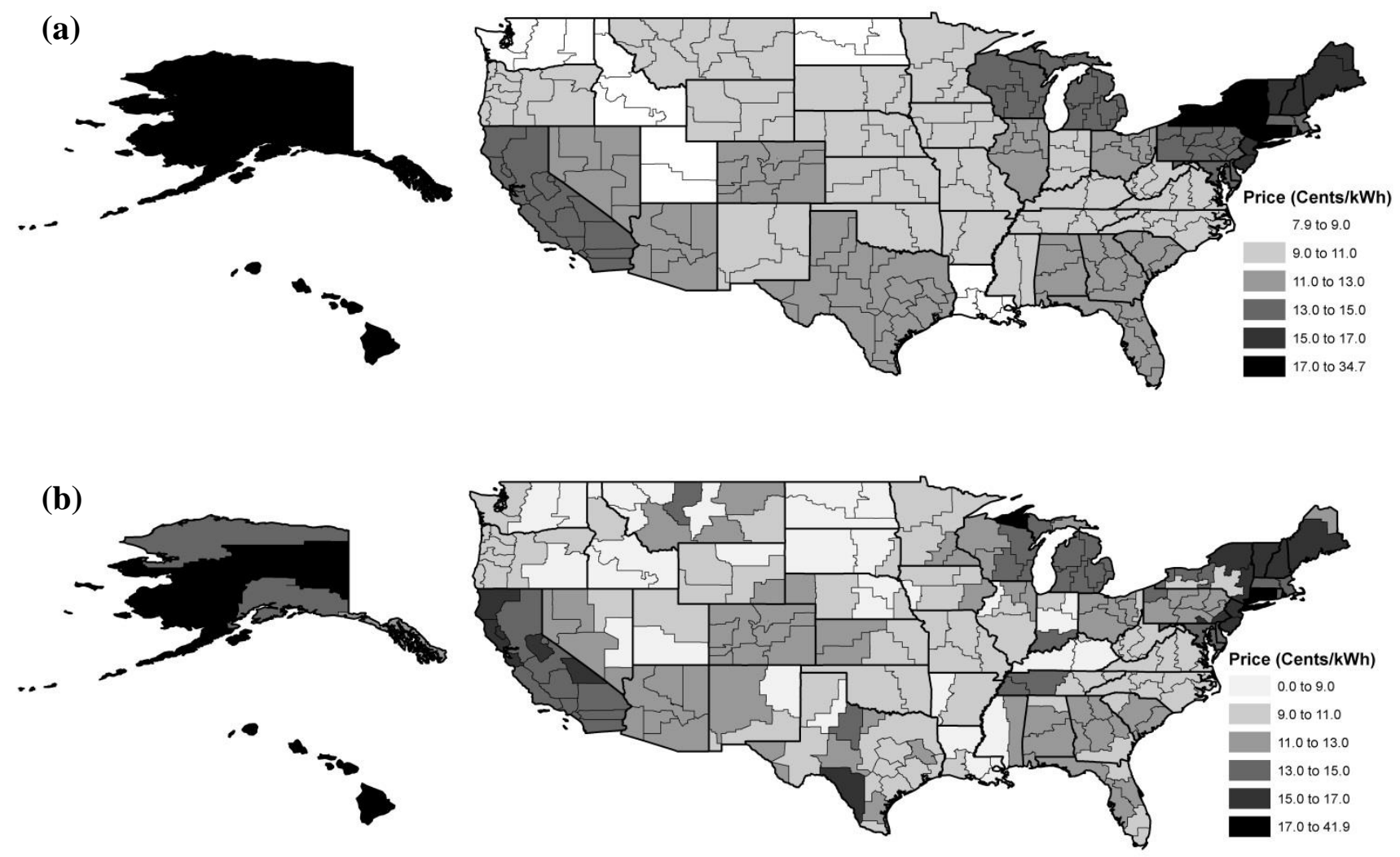

Figure 2-1 Electricity Price (Cents/kWh) by (a) State Average and (b) County Cluster

For example, the state average price for the state of New York is $19.5 \notin / \mathrm{kWh}$. However, as shown in Figure 2-2, the average price by city cluster ranges from $10.8 \notin / \mathrm{kWh}$ for Binghamton to 
$25.6 \notin / \mathrm{kWh}$ for New York City. As a result, the estimated electricity cost savings estimates could be too high or too low for each city cluster in New York State.

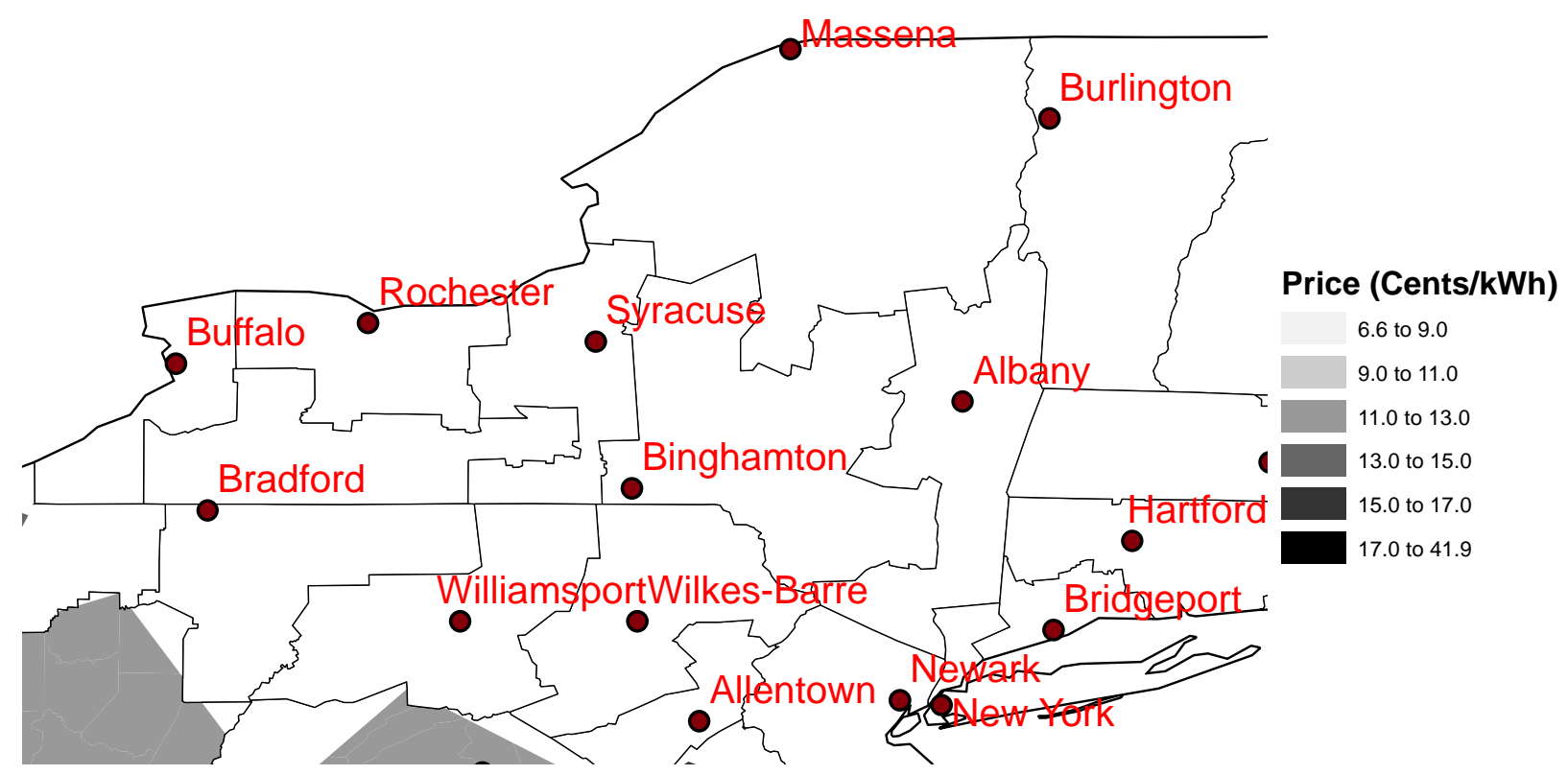

Figure 2-2 Average Electricity Price (Cents/kWh) by City Cluster for New York

Figure 2-3a and Figure 2-3b show that variation across city clusters in electricity prices is greater in some states than others. Over half of U.S. states (27) realize variation of less than $2 \phi / \mathrm{kWh}$, six Northeastern states have no variation because the states are relatively small and have only one city cluster for the state. Eleven states realize variation of $2 \phi / \mathrm{kWh}$ to $4 \phi / \mathrm{kWh}$, nine states realize variation of $4 \phi / \mathrm{kWh}$ to $8 \phi / \mathrm{kWh}$, and three state realize price variation of greater than $8 \notin / \mathrm{kWh}$. Similarly, 27 states realize less than a $20 \%$ variation in city cluster electricity prices (relative to state average prices), 18 states realize a $20 \%$ to $50 \%$ variation, and five states realize a greater than $50 \%$ variation in city cluster electricity prices (Figure 2-3b). 
(a)

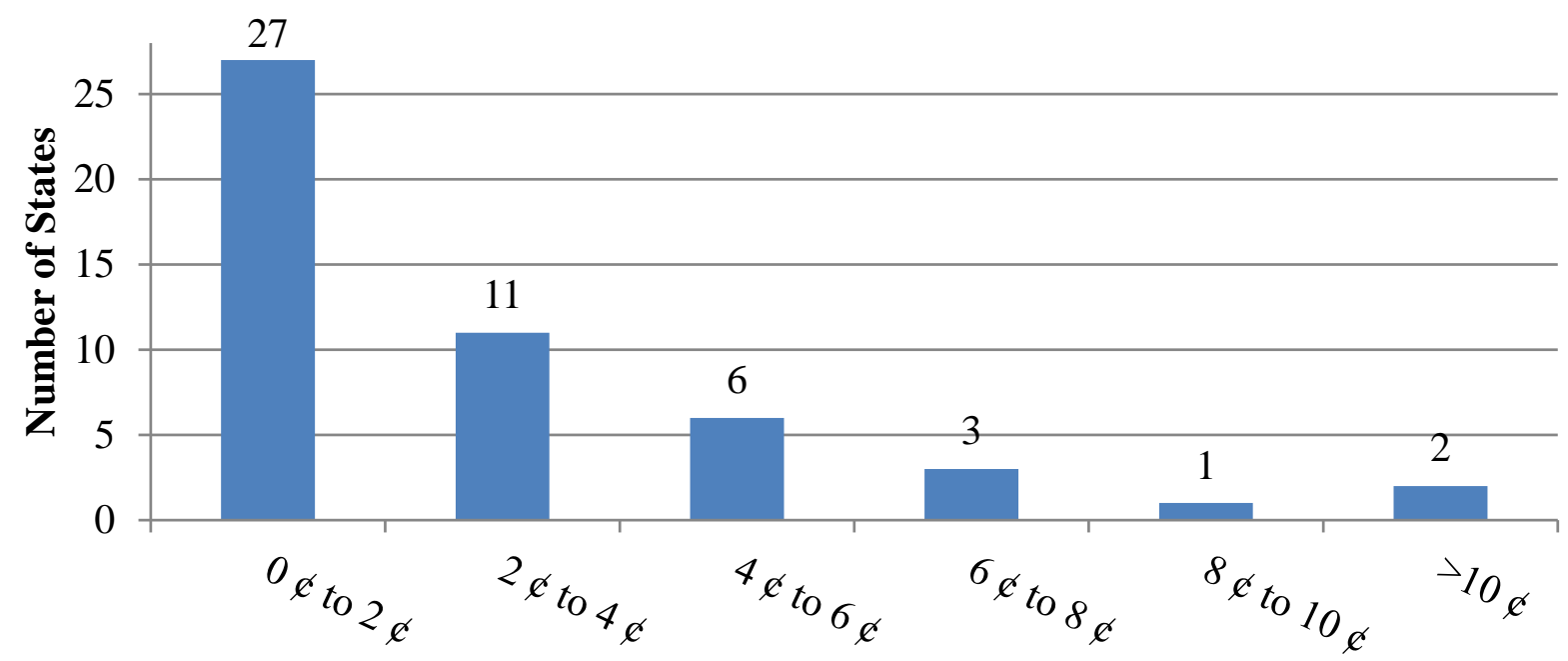

(b)

Variation in Electricity Price

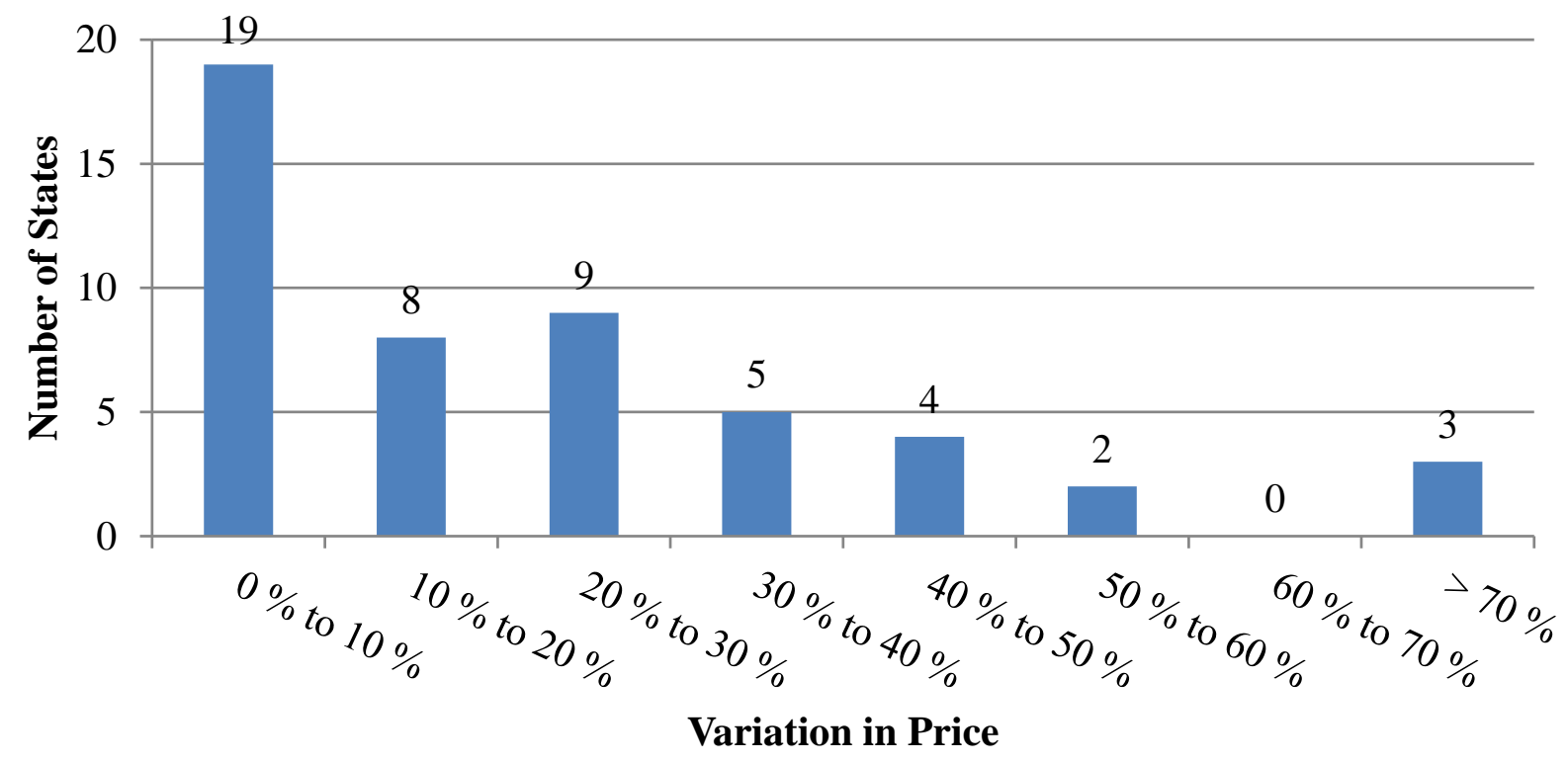

Figure 2-3 Variation in City Cluster Electricity Prices by State in (a) Cents/kWh and (b) Percentage of State Average

Figure A- 1 shows the variation for each of the 50 states in greater detail, including each state's average price, minimum city-cluster price, and maximum city cluster price. There is not a strong correlation between the state average electricity price and the variation in city-cluster prices across a state. Three of the top eight states in terms of highest state average price realize large variation in city cluster prices. However, there is also significant variation in some states with electricity prices within $1 \varnothing$ of the median state average price $(11.1 \phi / \mathrm{kWh})$. 
The three states that realize the greatest magnitude variation in electricity prices are Alaska, Hawaii, and New York (Table 2-1). Alaska is the largest state in the U.S. and has remote areas with varying access to fossil fuel sources in which electricity may be more expensive to produce and/or distribute, which leads to the greatest variation in electricity prices of any state in both magnitude $(25.7 \phi / \mathrm{kWh})$ and percentage relative to the states average price (168\%). Similarly, electricity production is expensive on all islands of Hawaii due to its isolation and lack of fossil fuel resources. The variation is much larger in magnitude than in percentage terms $(9.9 \phi / \mathrm{kWh}$ or $28 \%)$. New York realizes the second largest variation in prices in both magnitude and percentage (14.8 $\varnothing / \mathrm{kWh}$ and $76 \%$, respectively) across the state due to demographics. New York City residents face high prices $(25.6 \varnothing / \mathrm{kWh})$ due to the high electricity demand in a densely populated location while the rest of the state pays much lower prices, which are as low as $10.8 \phi / \mathrm{kWh}$.

The variation in percentage terms is highly correlated to the variation in absolute terms. After Hawaii and New York, the states that realize the greatest percentage changes are Texas $(65 \%)$, Montana (65\%), and Indiana (60\%) followed by Michigan (45\%), Nevada (42\%), and Iowa (41\%). All of which are also in the top 10 in terms of magnitude change.

Table 2-1 Top 10 - State Average Price and Variation in City-Cluster Electricity Prices (Cents/kWh and Percentage)

\begin{tabular}{|c|lr|lr|lr|}
\hline Rank & STATE & $\begin{array}{r}\text { State Avg. } \\
\text { Price* }\end{array}$ & STATE & $\begin{array}{r}\text { Variation - } \\
\text { Absolute }\end{array}$ & STATE & $\begin{array}{r}\text { Variation - } \\
\text { Percentage }\end{array}$ \\
\hline 1 & HAWAII & 34.7 & ALASKA & 25.7 & ALASKA & $168 \%$ \\
2 & NEW YORK & 18.3 & NEW YORK & 14.8 & NEW YORK & $76 \%$ \\
3 & CONNECTICUT & 18.1 & HAWAII & 9.9 & TEXAS & $65 \%$ \\
4 & ALASKA & 17.6 & MONTANA & 6.9 & MONTANA & $65 \%$ \\
5 & NEW HAMPSHIRE & 16.5 & TEXAS & 6.6 & INDIANA & $60 \%$ \\
6 & VERMONT & 16.3 & MICHIGAN & 6.1 & MICHIGAN & $45 \%$ \\
7 & NEW JERSEY & 16.2 & INDIANA & 5.9 & NEVADA & $42 \%$ \\
8 & MAINE & 15.4 & NEVADA & 4.9 & IOWA & $41 \%$ \\
9 & CALIFORNIA & 14.8 & IOWA & 4.5 & ILLINOIS & $36 \%$ \\
10 & MASSACHUSETTS & 14.7 & ILLINOIS & 4.3 & NEBRASKA & $34 \%$ \\
\hline
\end{tabular}

In summary, only 19 states realize minimal variations in electricity prices $(<10 \%)$ across the state. In fact, 15 states realize variation in electricity prices of greater than $30 \%$, which could lead to significant impacts on estimated future electricity cost savings over the lifetime of a building. Since the life-cycle cost-effectiveness of increases in energy efficiency of a building is driven by the future energy cost savings, the variation in electricity prices could increase or 
decrease the economic incentives of increasing energy efficiency in buildings, either through state building energy codes or retrofit efforts. 


\section{Discussion, Limitations, and Future Research}

This study implements an approach to associate every county in the U.S. to one of the 228 cities included in the BIRDS database to create multi-county "city clusters," and matches city-level average residential electricity costs to all counties in a city cluster to determine the variation in electricity prices across each state and the potential impact the variation may have on energy cost savings estimates based on the BIRDS database.

\subsection{Analysis}

Electricity prices not only vary across states ( $7.7 \phi / \mathrm{kWh}$ to $35.4 \phi / \mathrm{kWh})$, but can vary across city clusters within a state. This variation leads to a state average price that is not truly representative of some, if not all, locations within the state. Variation across city-clusters in electricity prices is greater in some states than others, varying from $0 \phi / \mathrm{kWh}$ and $0 \%$ to $26 \phi / \mathrm{kWh}$ and $168 \%$ of the state average price. The variation in percentage terms is highly correlated to the variation in absolute terms. The three states that realize the greatest magnitude variation in electricity prices are Alaska, Hawaii, and New York. Alaska and Hawaii are remote areas and face unique factors that can lead to higher prices statewide as well as variation across cities in the state. New York realizes large variation in prices across the state due to the demographic differences across the state due to New York City, which is a more densely populated, higher electricity demand market than the rest of the state.

In summary, only 19 states realize minimal variations in electricity prices $(<10 \%)$ across the state. In fact, 15 states realize variation in electricity prices of greater than $30 \%$, which could lead to significant impacts on estimated future electricity cost savings over the lifetime of a building. Since the life-cycle cost-effectiveness of increases in energy efficiency of a building is driven by the future energy cost savings, the variation in electricity prices could increase or decrease the economic incentives of increasing energy efficiency in buildings, either through state building energy codes or retrofit efforts.

\subsection{Limitations and Future Research}

This study attempts to improve upon the analysis approach from previous research using the BIRDS database. Based on the results, it appears that accounting for city-level variation in electricity prices may impact the life-cycle costs analysis of energy efficiency improvements of whole buildings. The city cluster approach described in this study begins to address this issue. However, there are still aspects of this approach that can be improved upon to increase the accuracy of the results.

First, the cluster approach is restricted by state borders even though the closest city may be in a bordering state. An example of this can be seen in Figure 3-1, where the counties within Kentucky and the surrounding states are mapped to a city that is often much further away than a city in another state. As a result, the climatic and economic conditions for those counties may not 
be matched to the best city in the database. However, each state has its own electricity market regulations and electricity distribution system infrastructure, which could lead to a city within the same state to be more representative of the electricity market for a given location. Further research is required to determine if the correlation in electricity prices is driven more by geographical location, state border, electrici utility boundary, or some combination of the three.

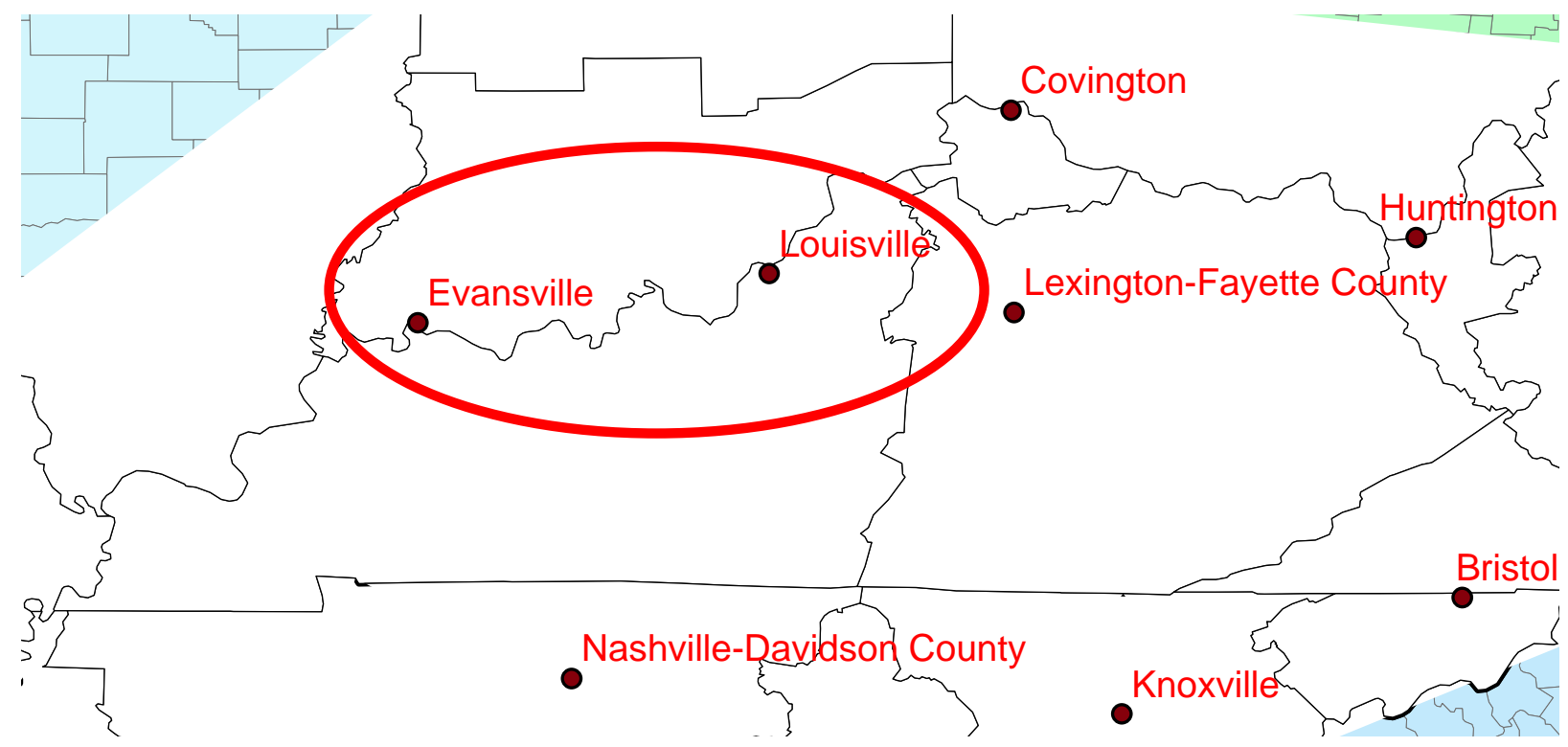

Figure 3-1 City Clusters - Kentucky and Surrounding States

Second, the analysis focuses on 2011 residential electricity prices. The same approach should be applied to both more recent residential prices as well as commercial electricity prices. Having both residential and commercial city-cluster prices will allow future analysis of the BIRDS database as additional data (new and retrofit residential and retrofit commercial buildings) is incorporated into BIRDS.

Third, this study focused solely on the variation in electricity prices without addressing the impact this variation would have on the previous analysis of the BIRDS database. Future work should incorporate these city-cluster prices into the calculation of statewide aggregate electricity cost savings and life-cycle cost analysis, both for new construction and energy efficiency retrofits. 


\section{References}

ArcMap 10.2 software, ArcGIS desktop package, ESRI, Redlands, CA, http://www.esri.com/.

J. Kneifel, 2011, Prototype Commercial Buildings for Energy and Sustainability Assessment: Whole Building Energy Simulation Design, September 2011, NIST, Technical Note 1716.

J. Kneifel, 2012, Prototype Commercial Buildings for Energy and Sustainability Assessment: Design Specification, Life-Cycle Costing and Carbon Assessment, January 2012, NIST, Technical Note 1732.

J. Kneifel, 2013a, Benefits and Costs of Energy Standard Adoption in New Commercial Buildings, February 2013, NIST, Special Publication 1147.

J. Kneifel, 2013b, Benefits and Costs of Energy Standard Adoption in New Commercial Buildings: Northeast Census Region, February 2013, NIST, Special Publication 1148-1.

J. Kneifel, 2013c, Benefits and Costs of Energy Standard Adoption in New Commercial Buildings: Midwest Census Region, February 2013, NIST, Special Publication 1148-2.

J. Kneifel, 2013d, Benefits and Costs of Energy Standard Adoption in New Commercial Buildings: South Census Region, February 2013, NIST, Special Publication 1148-3.

J. Kneifel, 2013e, Benefits and Costs of Energy Standard Adoption in New Commercial Buildings: West Census Region, March 2013, NIST, Special Publication 1148-4.

J. Kneifel and D. Butry, 2014, Impact of More Precise Construction Data on Estimated Savings from Energy Standard Adoption for Commercial Buildings, September 2014, NIST, Special Publication (forthcoming).

Energy Information Administration, 2012, Table 5.6.A. 2011 Average Retail Price of Electricity to Ultimate Customers by End-Use Sector, by State, http://www.eia.gov/electricity/data.cfm\#sales

Energy Information Administration, 2012, Table 6: 2011 Utility Bundled Retail SalesResidential, http://www.eia.gov/electricity/data.cfm\#sales 


\section{A Electricity Prices by State}

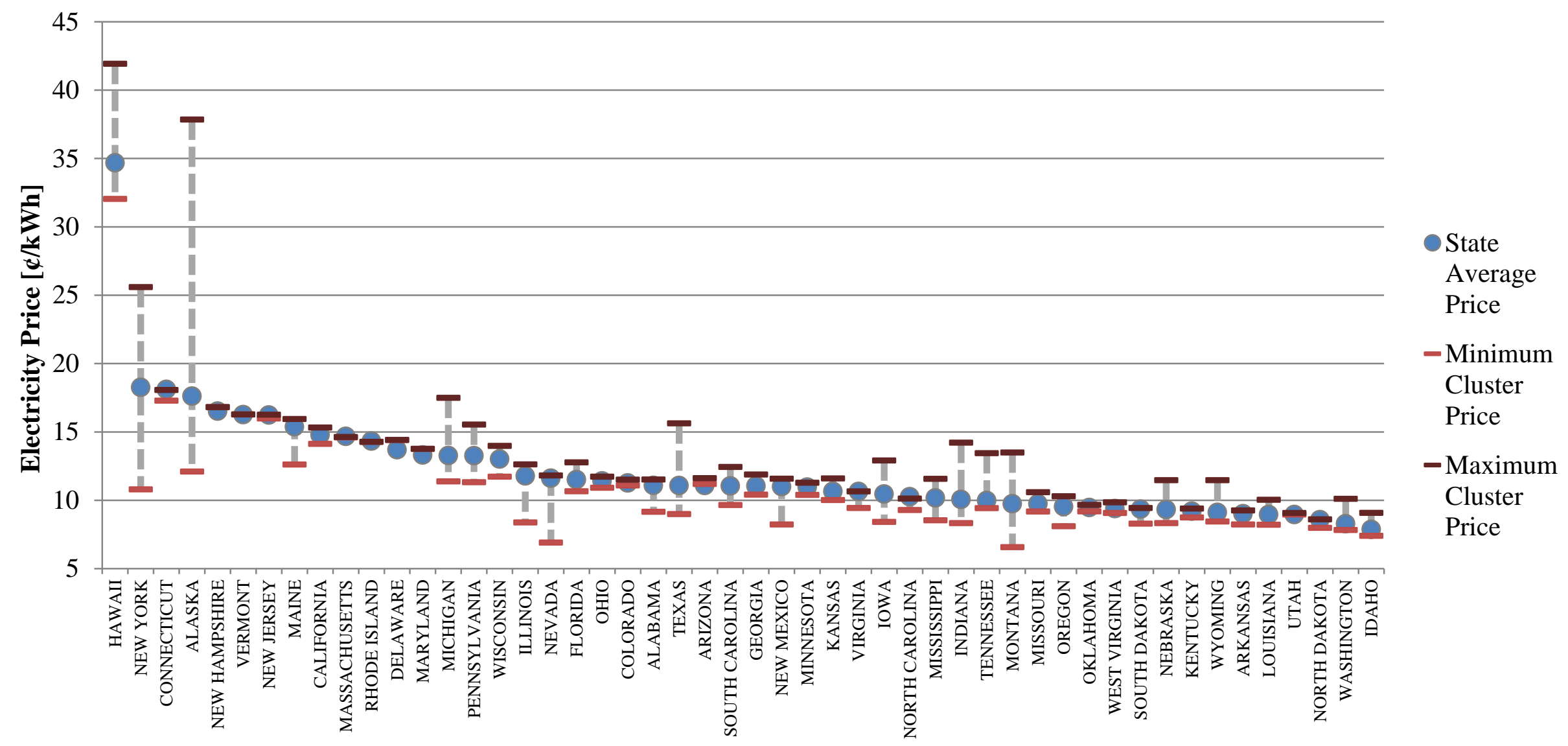

Figure A-1 Electricity Price by State Average and County Cluster (Cents/kWh)

\footnotetext{
${ }^{5}$ The average city cluster prices only include the sales associated with utilities that sell electricity in the 228 cities in the BIRDS database. As a result, there may be sales of electricity in a state that are not included in the city cluster prices, leading to the state average price being outside the range of city cluster prices. For example, Baltimore is the only city located in Maryland in the BIRDS database. The average price for the other locations in the state is lower than the city cluster price, leading to a state average price that is lower than the city cluster price.
} 